\title{
Impact of Ownership Structure on Dividend Policy: Case Study of the Listed Oil and Gas Companies in
}

\section{Vietnam}

\section{Le Duc Hoang, Nguyen Tuan Anh, Nguyen Que Phuong, Ta Thu Phuong}

National Economics University

Corresponding Author, Le Duc Hoang: hoangnhtc.neu@gmail.com

Received 26 July 2020;

Accepted 09 August 2020;

Published 20 August 2020;

\begin{abstract}
The study examines the effect of ownership structure on dividend policy in oil and gas companies listed on the Hanoi Stock Exchange and Ho Chi Minh Stock Exchange. Using panel data from 21 oil and gas companies from 2010 to 2015, we find that dividend payout is negatively related to state ownership and institutional ownership. Our results show that state and institutions have unfavorable ties to cash dividends, indicating signs of corporate capital being expropriated by large shareholders. Moreover, we do not find a significant relation between foreign ownership and dividends. Overall, our findings suggest that oil and gas companies need adjustments in their ownership structure to reduce the concentration of state and institutional ownership to improve the effectiveness of business and financial policies.
\end{abstract}

Keywords: Dividend policy, dividend payout ratio, ownership structure, state ownership, foreign ownership, institution ownership.

\section{Introduction}

Dividend policy is an important corporate financial policy with the ultimate goal of maximizing the shareholder value. Ownership structure is one of the powerful factors affecting corporate governance, thereby affecting corporate financial decisions such as financing decisions, investment decisions, and distribution decisions.

The relationship between ownership structure and dividend policy has attracted many studies by many scholars and economic managers (eg. Kang, 1999;Khan, T., 2006; Wen and Jia, 2010). However, how ownership structure affects dividend policy remains a matter of debate in corporate finance that scholars have been interested in investigating using different approaches and applying different techniques into different markets.

Although there have been many researches worldwide and in Vietnam that study the relationship between ownership structure and dividend policy, the results have not been consistent, due to the differences in business environment and governance regulations. These studies in general tried to explain the dividend behavior over time using past dividends, earnings, taxes etc. However, to the best of my knowledge, none of the previous studies in Vietnam tries to explain the behavior of pay-outs with respect to ownership structure or corporate governance. In this study, we seek to examine the shifting form of ownership structure along with the discrepancies in the dividend payment policies of the company.

The ownership structure of Vietnam is different from many countries in the world. The state ownership accounts for a relatively high proportion in many listed companies, in addition to the ownership of foreign investors do not exceed $49 \%$ of equity of a public company. The same is true for the oil and gas $(O \& G)$ industry in particular.

Besides, most previous studies centered on the effect of the ownership structure on firm efficiency, and limited research investigates the connection between ownership structure and dividend policy. Additionally, the O\&G industry is a key economic sector of the country, contributing greatly to the development of Vietnam. The O\&G industry in general always make significant contributions to the state budget revenue, making an important contribution to Vietnam's annual GDP growth. Empirical research on dividend policy in Vietnam has been conducted on the whole market, but not yet for a specific industry such as the Oil \& Gas industry.

This study studies empirically the relationship between ownership structure and dividend policy using data of 21 listed oil \& gas companies from 2010 to 2015 in Hanoi Stock Exchange (HNX) and Ho Chi Minh Stock Exchange (HOSE). Given the scope and data constraints, our study focuses on studying the impact of state ownership, foreign ownership, and institution ownership on corporate payout policy.

Our research make several important contributions. This research adds to the empirical evidence of the effect of ownership structure on dividend policy. Our findings help managers and executives plan appropriate financial strategies to enhance the value of the company. Besides, our paper provides investors important implications to assess and make decision to invest in stocks that they want to hold.

\section{Backgrounds and Literature Review}




\section{Dividend Policy}

Dividend policy, or payout policy, is one of the most important financial policies of the company. Dividends may be described as the distribution, in proportion to their ownership, of the earnings of the company to the firm's shareholders. While managers decide over time on the size and pattern of cash distribution to shareholders, the firm's aim is to maximize the present shareholders' wealth. A company's dividend policy has implications for all of its stakeholders. Higher dividend payouts lead to lower retained earnings and capital gains because more dividends will mean fewer funds available for reinvestment in future growth opportunities.

Previous studies have documents various theories on dividends. The dividend irrelevance theory (Modigliani and Miller, 1961) contents that dividend policy has no effect on the market value of a company or its capital structure. Bird-in-the-hand theory (Gordon, 1962) notes that shareholders are risk-averse and prefer to receive dividend payments because they think dividends are less risky than potential future capital gains. Besides, high payouts help eliminate agency costs by reducing the amount of free cash flow that managers can waste and exposing firms to more scrutiny when raising external capital. According to the signaling hypothesis, investors view dividend changes as signals of management's view of the future. Since managers hate to cut dividends, they are unlikely to raise dividends unless they think the raise is sustainable. Thus, a stock price increase as a result of dividend increase could reflect investors' higher expectations for future profitability, not a desire for dividends. Besides, agency theory suggests that dividend policy becomes the reason for conflicts between the companies 'managers and shareholders because of the managers' motive to retain resources for personal consumption or for investments in negative NPV projects instead of paying dividends to shareholders. On the other hand, the higher the dividend payout is, the smaller would be the amount available for debt servicing and claims redemption. Thus, excessive dividend payments at the expense of creditors are another example of the agency's problem (Jensen and Meckling, 1976; Smith and Warner, 1979).

\section{Ownership Structure}

Corporate governance is a significant initiative to maintain transparency and responsibility and a collection of values to be implemented into all areas of the company. Corporate governance theoretical position notes that the ownership of the company by the stakeholders will be expanded as much as possible. In fact, the purpose of this role is to straighten capital market control through means such as stock ownership, institutionalized shareholder tracking at general shareholder meetings and corporate takeover. In reality, corporate governance and monitoring mechanisms have increasingly focused on issues such as the structure of the board of directors, the roles and obligations of the executive directors, daily monitoring by shareholders, anti-acquisition devices, shareholder voting rights and accurate disclosure of business knowledge that is important to stakeholder decision taking. The framework for corporate governance will protect and promote the exercising of shareholder rights.

In the broad context of corporate governance, the question of ownership structure is an important subject (Alireza and Ali, 2011). Jensen and Meckling (1976) describe ownership structure as capital contributions consisting of both internal investors (managers and employees) and external investors (outside shareholders). Chaganti and Damanpour (1991) claim two ways of classifying ownership. The first distinguishes between those who directly affect firm decisions and activities - a situation that is called 'involvement' - and those who do not, which is called 'detachment'. The second way distinguishes firms that have stocks concentrated with some shareholders, which is called 'concentration', and firms whose stocks are dispersed to many shareholders, called 'dispersion'. They noted that shareholders whose ownership are more involved and concentrated have a strong influence on firm performance. Ezeoha and Okafor (2010) list ownership structure as the percentage of managers' shares (managerial ownership), institutions (institutional ownership), government (state ownership), foreign investors (foreign ownership), family (family ownership), and so on.

In general, ownership structure can include both inside and outside owners. Managers and staff are inside owners, and individuals, organizations, and state are outside owners. It is also possible to identify owners as foreign and native.

State Ownership. Compared to those with other types with ownership, it is well known that state-owned corporations typically under perform. Shleifer (1998) claims that lack of opportunities for government workers to optimize performance in terms of both cost savings and quality innovation is the key reason for inefficient state ownership. Studies on Chinese firms (Zou and Xiao, 2006; Li, Yue, and Zhao, 2009) and Russian firms (Pöyry and Maury, 2010) point out that state ownership was strongly associated with leverage. The main reasons include their greater ability to borrow in the external debt markets due to lower risk of default and more favorable treatment by state-owned banks, state owners' need to prevent dilution of assets or to maintain control of them, and using the debt as a monitoring channel to reduce considerable agency costs of equity in state-owned enterprises (Zou and Xiao, 2006).

Institutional Ownership. Because of their ability to better analyze information, provide new technologies and capital, and create more well-thought-out corporate governance system, institutional investors are enhancing enterprise efficiency the most. However, the efficiency may be reduced because the controlling organization may have different objectives than the maximization of profit.

Foreign and Domestic Ownership. The management may use various techniques against foreign investors, including illegal declaration of some of their shares, loss of voting records and so on. Domestic investors have more ways of defending their rights, including stronger relations with other shareholders, courts and even the physical forces (Shleifer et al. 1997; Ashland and Boone, 2002).

The relation between dividend policy and ownership structure A substantial theoretical and empirical literature have examined the relationship between dividend policy and corporate governance and ownership structure. Lim Hua Min (2004) asserts that "The best test of good governance is to pay good dividends." LaPorta et al. (2000) outline and test two agency models namely, "outcome model" and "substitute model". They document a positive relationship between corporate governance and dividend policy and express their assurance of higher dividends in well-run firms as a result of lucrative capital release pressure on insiders from minority shareholders. This is opposite to their alternative perspective that weak governance increases the need to offer cash as dividends to solve issues with agencies. Short et al. (2002) propose that a negative relationship exists between managerial ownership and dividend payout policy. Wen and Jia (2010) find a 
negative relation between dividend policy and both managerial ownership and institutional ownership in bank holding companies.

Bhattacharya (1979-1980), Linter (1956), Lintner (1962-1970), Miller and Rock (1985) suggest that the corporate dividend policy is structured to give investors earnings prospects. There might also be interrelationships between the distribution payout policy and the business costs (Easterbrook 1984, Jensen and Meckling 1976). Bhattacharya (1979-1980) shows that dividends are signals of future cash flows. Black and Scholes (1974) measures the impact of dividend yield on stock returns, after declaration of dividend. Gorden (1959) in his seminal work proposes that "even in presence of perfect capital markets, the existence of uncertainty about the future cash flow, suffices to make the price of shares dependent upon the dividend policy". Miller and Modigliani (1961) analyze the impact of a dividend strategy on the selling price of the shares.

Gugler (2003) examines the connection between distributions and the company's ownership and management system for Austrian companies. Faccio et al. (2001) provide quantitative evidence of expropriation within the business group and of differences between Europe and Asia in expropriation. Gugler and Yurtoglu (2003) clarify why dividends may be insightful. Fukuda (2000) uses Japanese evidence to check the dividend signaling theory. Aivazian et al. (2003) find that "emerging market firms exhibit dividend behavior similar to those of US". Amihud and Murgia (1997) use German data to investigate the relationship of dividends, taxes and signaling.

Kang (1999) studies the U.S. textile industry and finds that early-generation (generation one to three) family shareholders had higher dividend payout rates, while later-generation (generation four to seven) family shareholders had lower dividend payout rates. Nevertheless, businesses with later-generation family owners who had very significant ownership stakes reported higher dividend payout rates. These findings indicate that early-generation family owners are successful in corporate governance, that latergeneration family owners may be especially inefficient in influencing the dividend policy, and that influential latergeneration family owners may use their influence to obtain financial benefits. Faccio et al. (2001) analyze dividend expropriation and find that (1) group-affiliated companies in Europe are paying higher dividends than in Asia; and (2) closely associated parties that power ties still surpass $10 \%$ but do not reach $20 \%$ may not pay higher dividends, and the broader gap between ownership and control is related to lower dividend levels. This research indicates that various ownership arrangements influence the rates of payment of the dividends.

Jensen et al (1992) and Short et al. (2002) find that the paying of dividends is in the opposite direction of insider ownership as it is not appropriate to offer large dividends at the same period because the equity of management is small. However, according to Farinha (2003), this opposite relationship is only acceptable before a crucial point of enclosure; after that stage, ownership and dividends must make up for each other. Ownership can be reflected, as used in Khan (2006), not only by management ownership but also by the concentration of ownership in shareholding chains. Whereas Khan (2006) find a negative relationship between dividends and ownership concentration in UK firms; Naceur et al. (2006) discover that ownership concentration does not impact dividend policy in Tunisia as increasing dividends are not encouraged because Tunisian corporate agency conflicts are not so high. Overall, previous research show conflicting findings on the effect of ownership, including management ownership or ownership concentration on dividend policy.

\section{The research gap}

Ownership structure has a direct impact on the management and operation of the business, and accordingly affecting corporate financial policies, including dividend policy, and the value to shareholders. Although a number of research have been carried out on dividend policy, there have been few in-depth investigations on Vietnamese firms. Furthermore, studies on ownership structure and dividend policy in Vietnam has been facing several shortcomings. In particular, most studies considers only state ownership and only few research examined the impact of other forms of ownership, such as foreign ownership. Studies on Vietnamese companies also fail to control for variables such as size, ROA, etc. Meanwhile, there is very little quantitative analysis on the relationship between ownership structure and dividend policy using panel data and appropriate statistical approaches. Thus, all of these drawbacks highlight the need for more throughout studies in Vietnam.

\section{Oil \& Gas industry situation}

\section{Global Oil \& Gas Industry}

Crude oil is one of the commodities that are most present and important in daily life. The oil \& gas industry is one of the biggest industries of the global economy. About four billion metric tons of oil are produced annually worldwide. In the Middle East area, nearly one third of that amount is produced. Saudi Arabia and the United States are the top oil producers in the world, together accounting for about 13 percent of overall global supply. Russia is the third biggest producer, accounting for more than $12 \%$ of the overall world oil output. Gasoline use is continuously growing in the US, where usage is one-quarter of the world's production, and this is also occurring in emerging economies, especially India, China, and Russia. Only in European countries, the demand hardly increased.

During the 2010-2015 period, non-OPEC mining production is on the decline. It is worth noting that in the latest complicated oil price war, US supply raises or decreases in its overall long-term plan for negotiating with other big oil exporting countries. The rise in US gas production comes from shale gas, combined with the strong gas storage capability that supports reliably low US gas prices relative to other global markets. Oil reserves of most countries which have oil and gas resources decreased. In other words, the annual increase in reserves does not compensate for the output exploited in that year.

Between mid-2014 and early 2016, the world economy was hit with one of the biggest oil-price drop in recent times. The price downturn of 70 percent during that period was one of the three largest drops since World War II and the longest since the supplydriven slump in 1986 . The causes included over-supply as the tight oil (shale oil) production in the US and Canada exceeded critical thresholds, geopolitical rivalries across oil-producing nations, declining demand through commodity markets as a consequence of the deceleration of the Chinese economy, and future long-term demand decline as an environmental strategy promotes fuel production and reduces the share of fossil-based energy use.

The fall in oil prices had a strong and lasting impact on the economic activity of the oil exporters. While the market's anticipation of prolonged oil price weakness may explain this bearish divergence, the continued focus the industry puts on financial results, shareholder dividends and free cash flows should not be overlooked for a long time-it has the capacity to help it recover the interest of investors in the times to come.

Vietnam Oil \& Gas Industry 
Considered as a country with great potential of oil and gas reserves, Vietnam ranks 28th out of 52 countries in the world with oil and gas resources. Oil and gas industry is a key economic sector dominated by state-owned corporations such as the Vietnam Oil and Gas Group (Petrovietnam or PVN), Vietnam National Petroleum Group (Petrolimex), etc., which have contributed greatly to the State budget revenue, the export turnover, and attracting foreign investors to Vietnam. PVN has given close to 70 per cent of domestic oil and gas facilities and is also a commercial associate with numerous international oil and gas firms. Regarding budget contribution, before PVN had an oil refinery, the total annual revenue from crude oil always brought over $20 \%$ of the total budget revenue. After that, the average rate of crude oil revenue for the period of 2009-2013 reached an average of $13.6 \%$. Due to the impact of the sharp decline in oil prices in 2015, this figure was only at 62.4 trillion and contributed $7.1 \%$ of the total budget.

In the context of the world and domestic economic situation facing many difficulties, the sharp decline of oil prices from October 2014 has also greatly affected PVN's operations. It is increasingly difficult for PVN due to the implementation in deep offshore, leading to the declines in revenue. Many projects of PVN have large investment capital so the pressure on capital arrangement is very large. As a result, while total assets of Vietnamese oil and gas companies grew at a rapid rate from 20102013, its growth rate is lower in 2014 and become negative in 2015. Also, the leverage ratio increased sharply during 2013-2014, but decrease in 2015. In addition, the return on assets (ROA) of Vietnamese oil and gas companies plummeted in 2013 and 2014, but has also started to rebound slightly in 2015 .

\section{Hypothesis Development}

State ownership in Vietnam is very similar to that of Chinese firms, where the equalization of major corporations with predecessor SOEs happened. Companies with high levels of state ownership also have a long history of state-sponsored activities. These businesses are less constrained by financial restrictions, though Vietnam's corporate bond sector is relatively small, but stateowned enterprises are readily accessible to banking system financing with a select number of banks. On the other hand, in order to make successful divestment in businesses with high state ownership, a good dividend policy can help to attract investors in the market. Following these discussions, we state our first hypothesis as follows:

H1a: Dividend payout is positively related to state ownership. On the other hand, government ownership is usually considered as a source of inefficiency. This is because managers of statecontrolled firms are less subject to external monitoring by markets and are not evaluated by the achievement of value-maximizing objectives but rather by the achievement of political objectives. Managers, who are poorly monitored in these firms (Borisova et al., 2012), thus have incentives to retain cash within the firm for their own benefit since it may be used for empire-building purposes (Hamdi Ben-Nasr, 2015). Also, shareholders of firms with weak corporate governance are less able to force managers to distribute cash through dividends. Thus, we predict that state ownership is negatively related to dividends and state our alternative hypothesis as below.

H1b: Dividend payout is negatively related to state ownership. By investigating the shareholder structure and management board composition in the annual reports of listed companies, we found that foreign investors had very little participation in the company's management board. Instead, they enter the market for merely seeking income like other individual investors in the market. With low and fragmented ownership, foreign investors have no incentive to control the board and it will be expensive for them to oversee corporate management behavior. Thus, they are unlikely to exert influence to the board to pay higher dividends. In this study, we expect a negative relationship between foreign ownership and dividends.

H2: Dividend payout is negatively related to foreign ownership. According to Zeckhauser and Pound (1990), high institutional ownership is considered a good signal because institutions are more effective in monitoring management activities and better at resolving conflicts of interest, thus mitigating agency costs. Thus, there may be an inverse relationship between institution ownership and dividend payout. Therefore, we expect a negative relationship between institutional holdings and dividends.

\section{H3: Dividend payout is negatively related to institutional ownership.}

\section{Data and Methodology}

\subsection{Variables Construction Dividend Payout}

We use dividend payout ratio, labeled DIV, as the dependend variable in our regression model. Dividend payout ratio, calculated by dividing Cash Dividend per share (DPS) by Earnings per share (EPS), reflects the percentage of profit after tax used to pay dividends. The greater dividend payout indicates the smaller retained earnings, and thus, limiting the internal funds that the company can spend to make future long-term investments. Vietnamese companies mostly pay cash dividends instead of other types of payment because shareholders feel more secured and paying cash dividends can demonstrate the health and stability of business's cash flow. Thus, our research will focus on the effect of ownership structure on the policy of paying cash dividends.

\section{Ownership variables}

We develop three ownership measures. First, we measure state ownership, labeled STATE, as the percentage of shares owned by state shareholders in total shares outstanding. Second, we measure foreign ownership, labeled FORG, as the percentage of shares owned by foreign shareholder in total shares outstanding. Third, we measure institutional ownership, labeled INST, as the percentage of institutional shareholders in total shares outstanding. We exclude state-owned and foreign institutional owners and only include domestic non-state-owned institutional shareholders in our calculation.

\section{Control variables}

Following previous studies, we control for several firm characteristics in the regressions. First, we control for leverage, labeled LEV, calculated as total debt divided by equity. Previous studies show that debt leverage negatively affects dividends. According to Jensen and Meckling (1976), Jensen (1986) and Stulz (1990), financial leverage plays a major role in managing managers' behavior and the operational costs of the shareholdersmanagers conflict. Jensen (1986) argues that the use of debt can minimize the need to use dividends to mitigate the conflicts between shareholders and dividends and the agencies. Therefore, the business principle of free cash flow expects a negative debt- 
dividend relationship. In fact, certain debt contracts may contain security covenants that restrict payouts. On the other hand, if more profits is retained, it will be used to finance the company's projects and repay debts to creditors, thereby reducing debt leverage and the need to raise debt from external market. Thus, we expect a negative relation between financial leverage and dividends.

Second, we control for company size, labeled SIZE, measured as the natural logarithm of total assets. Previous studies (Redding, 1997) suggest that the scale of the business affect dividend payout ratio, because large businesses are more likely to pay dividends. In particular, Titman and Wessels (1988) conclude that large corporations appear to be more stable, earn higher profits, and therefore have a lower risk of failure, which may lead shareholders to collect more dividends. Larger companies continue to grow, generate better free cash flows and are more prone to offer higher dividends relative to smaller firms. Thus, we expect a positive relationship between firm size and dividends.

Third, we control for return on assets, labeled ROA, calculated as the ratio of net income to average total assets. ROA is used to monitor the profitability of the company. High-profit firms prefer to offer higher dividends than businesses with lower profitability. Therefore, we expect a positive relationship between ROA and dividends.

Forth, we control for liquidity, labeled LID, measured as the ratio of current assets to current liabilities. This ratio represents the potential to turn cash into capital to compensate for short-term obligations, or the ability to pay the business' short-term obligations. Adelegan (2003) documents the existence of a significant relationship between dividends and cash flows. Farman Khan and Ahmad (2017) show that liquidity is among positive determinants of dividends. Therefore, we expect a positive relationship between liquidity and dividend payout ratio.

\subsection{Sample and data collection}

Our sample consists of 21 firms, representing all the oil and gas firms listed on Hanoi Stock Exchange and Ho Chi Minh Stock Exchange during the period 2010-2015. We collect dividend data and ownership information, as well as financial data from annual reports and online database.

\subsection{Methodology}

To investigate the relations between ownership structure and dividends, we run the regressions of dividend payout ratio on each ownership variable and control variables on our sample. We use both the Fixed Effect Model (FEM) and the Random Effect Model (REM) and later use Hausman tests to choose the right model. Our regression model has the following form:
$\mathrm{DIV}_{\mathrm{i}, \mathrm{t}}=\beta 0+\beta_{1} \mathrm{STATE}_{\mathrm{i}, \mathrm{t}}+\beta_{2} \mathrm{FORG}_{\mathrm{i}, \mathrm{t}}+\beta_{3} \mathrm{INST}_{\mathrm{i}, \mathrm{t}}+\beta_{4} \mathrm{LEV}_{\mathrm{i}, \mathrm{t}}+\beta_{5}$ $\mathrm{SIZE}_{\mathrm{i}, \mathrm{t}}+\beta_{6} \mathrm{ROA}_{\mathrm{i}, \mathrm{t}}+\beta_{7} \mathrm{LID}_{\mathrm{i}, \mathrm{t}}+\mathrm{e}_{\mathrm{i}, \mathrm{t}}(1)$

Table: 1: Summary of the dependent and independent variables

\begin{tabular}{|l|l|}
\hline Dependent Variable & \\
\hline $\begin{array}{l}\text { Dividend Payout ratio } \\
\text { (DIV) }\end{array}$ & Total Cash Dividends / Net Income \\
\hline Independent Variables & The percentage holding by the state \\
\hline STATE & $\begin{array}{l}\text { The percentage holding by foreign } \\
\text { shareholders }\end{array}$ \\
\hline FORG & $\begin{array}{l}\text { The percentage holding by } \\
\text { institutional shareholders }\end{array}$ \\
\hline INST & Total Debt / Total Assets \\
\hline Control Variables & The natural log of Total Assets \\
\hline Leverage (LEV) & Net Income / Average Total Assets \\
\hline Size (SIZE) & Current Assets/Current Liabilities \\
\hline ROA & \multicolumn{2}{|l}{} \\
\hline LID &
\end{tabular}

\section{Empirical Results}

\subsection{Descriptive statistics}

Table 2: Descriptive statistics

\begin{tabular}{|l|l|l|l|l|l|}
\hline Variable & N & Mean & Std. Dev. & Min & Max \\
\hline DIV & 126 & 0.447 & 0.597 & 0 & 4.348 \\
\hline STATE & 126 & 0.325 & 0.277 & 0 & 0.967 \\
\hline FORG & 126 & 0.104 & 0.129 & 0 & 0.489 \\
\hline INST & 126 & 0.427 & 0.248 & 0.009 & 0.935 \\
\hline LEV & 126 & 1.787 & 1.992 & 0.107 & 13.415 \\
\hline SIZE & 126 & $\begin{array}{l}28.34 \\
2\end{array}$ & 1.615 & 24.834 & 30.906 \\
\hline ROA & 126 & 0.056 & 0.096 & -0.544 & 0.334 \\
\hline LID & 126 & 1.697 & 1.222 & 0 & 6.988 \\
\hline
\end{tabular}

This table reports the descriptive statistics of the sample of 21 listed oil and gas companies over the period 2010-2015. The average dividend payout ratio (DIV) is 0.447 or $44.7 \%$. The DIV ratio of Vietnamese $O \& G$ companies varies significantly during the period from 2010 to 2015 with the minimum level of 0 and the maximum level of 4.34. We also noted that state ownership and institutional ownership of firms in our sample completely predominate at the average level of $32.4 \%$ and $42.6 \%$, respectively. Another point worth noting is that all three types of ownership are highly volatile with large distances.

\subsection{Correlation between variables}

Table 3: Correlation matrix between variables

\begin{tabular}{|l|l|l|l|l|l|l|l|l|}
\hline & DIV & STATE & FORG & INST & LEV & SIZE & ROA & LID \\
\hline DIV & 1.0000 & & & & & & & \\
\hline STATE & -0.098 & 1.000 & & & & & & \\
\hline FORG & 0.179 & -0.042 & 1.000 & & & & & \\
\hline INST & -0.137 & -0.530 & -0.297 & 1.000 & & & & \\
\hline LEV & -0.204 & 0.122 & -0.133 & -0.112 & 1.000 & & & \\
\hline SIZE & -0.071 & 0.253 & 0.500 & -0.129 & 0.254 & 1.000 & & \\
\hline ROA & 0.180 & 0.010 & 0.206 & 0.028 & -0.541 & 0.026 & 1.000 & \\
\hline LID & 0.244 & 0.124 & 0.197 & 0.114 & -0.341 & 0.022 & 0.535 & 1.000 \\
\hline
\end{tabular}

Table 3 presents the correlation matrix between the variables in our model. According to the correlation matrix, dividend payout ratio is negatively correlated with state ownership $(\rho=-0.098)$, institutional ownership $(\rho=-0.137)$, leverage $(\rho=-0.204)$, and size ($0.071)$, and positively correlated with foreign ownership $(\rho=0.179)$,
ROA $(\rho=0.180)$, and liquidity $(\rho=0.244)$. Among those, correlations of the independent variable FORG and the control variable LID with the dependent variable are the largest. These data imply that a high concentration of state and domestic ownership tends to lead to a decline in the DIV. On the other hand, 
despite accounting for a smaller percentage of ownership, foreign ownership has a positive impact on the dividend payout ratio of O\&G companies.

If the correlation between any two independent variables is greater than $0.8(\rho>0.8)$, it's highly likely that the model is subjected to multicollinearity (Bryman, 2006). Table 3 shows that none of the correlations between independent variables are lower than 0.8. Thus, the model is unlikely to suffer from multicollinearity.

\subsection{Regression results of Fixed Effects Model (FEM) and Random Effects Model (REM)}

We examine the relation between dividends and the ownership structure by running the regression model (1) on our sample. The dependent variable is dividend payout ratio, calculated by dividing the cash dividend payments to net income, and the test variables include state ownership, foreign ownership, and institutional ownership, measured as the percentage of ownership of state shareholders, foreign shareholders, and institutional shareholders, respectively. Control variables are defined in Table 1.

Table: 4. Regression results of FEM and REM

\begin{tabular}{|l|l|l|}
\hline Variable & FEM & REM \\
\hline STATE & $-1.030^{* *}$ & $-0.700^{* *}$ \\
\hline & $(0.021)$ & $(0.011)$ \\
\hline FORG & -0.967 & -0.088 \\
\hline & $(0.352)$ & $(0.886)$ \\
\hline INST & $-1.540^{* * *}$ & $-0.901^{* * *}$ \\
\hline & $(0.003)$ & $(0.003)$ \\
\hline LEV & -0.035 & -0.036 \\
\hline & $(0.447)$ & $(0.291)$ \\
\hline SIZE & -0.026 & -0.002 \\
\hline & $(0.912)$ & $(0.973)$ \\
\hline ROA & -0.038 & -0.172 \\
\hline & $(0.969)$ & $(0.814)$ \\
\hline LID & $0.195 *$ & $0.151^{* * *}$ \\
\hline & $(0.063)$ & $(0.007)$ \\
\hline Constant & 2.019 & 0.932 \\
\hline & $(0.762)$ & $(0.452)$ \\
\hline Observations & 126 & 126 \\
\hline R-square & 0.140 & 0.167 \\
\hline
\end{tabular}

This table reports the firm-level regression results of the dividend payout ratio. The dependent variable is the dividend payout ratio, DIV, measured as cash dividend divided by net income. STATE is the percentage of shares owned by the state. FORG is the percentage of shares owned by foreign shareholders. INST is the percentage of shares owned by institutional shareholders. Control variables are defined in Table 1. p-value is reported in parentheses. The unit of observations is the number of firm-year observations over the sample period. *, **, and *** indicate significance levels of the coefficients at the $10 \%, 5 \%$, and $1 \%$ levels, respectively.

Tables4 presents the results of FEM and REM models with dividend payout ratio as dependent variable. The results show that the coefficients on STATE and INST are negative and statistically significant at the 5\% and $1 \%$ level, respectively, in both models, suggesting negative relations between dividend payout ratio and state ownership and between dividend payout ratio and institutional ownership. The coefficient on FORG is negative but insignificant, suggesting that foreign ownership does not have significant relationship with dividend payout ratio. Our results also suggest that dividend payout ratio is positively related to liquidity as the coefficient on LID is positive and statistically significant at $10 \%$ level in FEM and 1\% level in REM.

\subsection{The Hausman test}

We use the Hausman test to identify the model that fits the data set in this study. The Hausman method is used to assess the option between fixed-effect regression (FEM) and random-effect regression (REM) (Baltagi, 2005). The hypothesis of this test is:

H0: No association between error and independent variable

H1: There are an association between error and independent variable

Table 5: The Hausman test results

\begin{tabular}{|c|c|c|c|c|}
\hline & (b) & (B) & $(b-B)$ & $\begin{array}{l}\text { sqrt }(\operatorname{diag}(\mathrm{V} \\
\text { b-V_B })\end{array}$ \\
\hline & $\mathrm{Fe}$ & $\operatorname{Re}$ & Difference & S.E. \\
\hline STATE & -1.0303 & -0.7001 & -0.3302 & 0.3413 \\
\hline FORG & -0.9674 & -0.0884 & -0.8791 & 0.8310 \\
\hline INST & -1.5401 & -0.9011 & -0.6389 & 0.4087 \\
\hline LEV & -0.0354 & -0.0363 & 0.0008 & 0.0313 \\
\hline SIZE & -0.0263 & -0.0016 & -0.0247 & 0.2328 \\
\hline ROA & -0.0377 & -0.1715 & 0.1339 & 0.6170 \\
\hline LID & 0.1952 & 0.1509 & 0.0443 & 0.0875 \\
\hline \multicolumn{5}{|c|}{$\begin{array}{l}\mathrm{b}=\text { consistent under } \mathrm{Ho} \text { and } \mathrm{Ha} \text {; obtained } \\
\text { from xtreg }\end{array}$} \\
\hline \multicolumn{5}{|c|}{$\begin{array}{l}\text { B = inconsistent under Ha, efficient under Ho; obtained from } \\
\text { xtreg }\end{array}$} \\
\hline \multicolumn{4}{|c|}{$\begin{array}{l}\text { Test: Ho: difference in coefficients not } \\
\text { systematic }\end{array}$} & \\
\hline \multicolumn{3}{|c|}{$\begin{array}{l}\operatorname{chi} 2(7)=(b-B)^{\prime}\left[\left(V_{-} b-\right.\right. \\
\left.\left.V_{-} B\right)^{\wedge}(-1)\right](b-B)\end{array}$} & & \\
\hline \multicolumn{2}{|c|}{$=5.10$} & & & \\
\hline \multicolumn{2}{|c|}{$\begin{array}{l}\text { Prob }>\text { chi } 2= \\
0.6482\end{array}$} & & & \\
\hline
\end{tabular}

Table 5 reports the Hausman test results for the FEM and REM models. The Hausman test shows that Prob> Chi2 $=0.6482$ is greater than 0.05 , so the hypothesis $\mathrm{H} 0$ is not rejected, meaning that there is no correlation between the error and independent variables. Thus, the REM model for evaluating the impact of the ownership structure on DIV should be chosen. We will hereafter use the results of the REM model.

\section{- $\quad$ Testing the suitability of the model}

Test of hypothesis: $\mathrm{H}_{\mathrm{o}}: \mathrm{R}^{2}=0$ (With significance level chosen as $\alpha$ $=5 \%$ )

$$
\mathrm{H}_{1}: \mathrm{R}^{2}>0
$$

In an unreported result, the p-value of the $\mathrm{F}$ test equal to 0.0018 , less than $5 \%$. Thus, we reject the hypothesis $\mathrm{H} 0$, meaning that the model chosen is appropriate and can be used for statistical analysis.

- Testing the influence of independent variables with dependent variable

Test of hypothesis : $\mathrm{H}_{\mathrm{o}}: \beta=0$ (With significance level chosen as $\alpha=$ $5 \%)$

$$
\mathrm{H}_{1}: \beta \# 0
$$

Considering the p-value of the variables of the model, we reject the hypothesis $\mathrm{H} 0$ for variables that produce the p-value results less than significance level 5\%, meaning that those variables have an effect on the dependent variable DIV.

\section{- Coefficient of determination $\left(\mathbf{R}^{2}\right)$}


From the regression results table, the value of $R^{2}$ is 0.1673 , meaning that the independent variables in the model can explain $16.73 \%$ of the change of the dependent variable. Although the impact is not really big, it is completely acceptable because the business characteristics of the O\&G industry are greatly influenced by many factors and the whole market.

From the results in Table 4, the regression model of dividend policy on ownership variables and control variables can be written as below.

DIV $=0.9318-0.7001$ STATE -0.0883 FORG -0.9011 INST 0.0362 LEV - 0.0016 SIZE - 0.1715 ROA + 0.1509 LID + e

Several results can be taken from the REM model. First, the coefficient of state ownership is -0.7001 and statistically significant at the $5 \%$ level with p-value equal to 0.011 . Thus, we can conclude that state ownership has a negative impact on dividend payout, which is consistent with our H1b hypothesis. The result suggests that firms with state ownership are less likely to pay high dividends because managers tend to keep cash in the firms to be used for their own benefits.

Second, we find that the institutional ownership is also inversely related to dividend payout ratio and the coefficient is statistically significant at the $1 \%$ level (p-value $=0.003$ ). Thus, the result supports our $\mathrm{H} 3$ hypothesis, suggesting that institutional investors helps mitigate agency costs and can force managers to increase payout.

Third, the results demonstrate that the coefficient of foreign ownership is negative (-0.088), but not statistically significant (pvalue $=0.886$ ). The finding suggests that there is no evidence of a relation between foreign ownership and dividends.

Among the control variables, only liquidity shows a positive and significant relationship with dividend payout ratio with a coefficient of 0.1509 and statistically significant $(p$-value $=0.07)$ at the $5 \%$ level. This shows that the better the liquidity of businesses, the higher the ability to pay cash dividends. All three remaining control variables, including leverage, firm size, and ROA, exhibits a negative relation with dividends but the results are not statistically significant.

\section{Discussion and Conclusion}

This paper examines the impact of ownership structure on the dividend policies of the listed Vietnamese oil \& gas firms for the period 2010-2015. As a frontier market that is rising from a smaller base and very close to being an emerging market, Vietnam is characterized by faster expansion, providing businesses with strong returns on investment opportunities. This may explain why Vietnamese companies retain more earnings, which translates into fewer dividend payments across all groups of ownership. During this period, O\&G companies worldwide and in Vietnam faced many difficulties, especially because of the 2010s oil glut. O\&G enterprises in Vietnam are having unreasonable ownership structures, particularly with the large proportion of state ownership and institution ownership, in contrast to the low percentage of foreign ownership.

Firstly, our empirical results show that both state ownership and institutional ownership have a negative effect on the dividend payout ratio of Vietnamese listed O\&G companies, consistent with predictions of agency theory. Both groups are major shareholders, who have a great influence on the company's dividend payment policy and what they like is to retain the profits to reinvest in order to bring more benefits to them in the future. They account for a high proportion and have a certain understanding of domestic businesses so they prefer to keep the profits to reinvest in order to benefit more in the future and to avoid paying personal income tax. The result reveals that state and institution holding have unfavorable ties to cash dividends, indicating signs of corporate capital being expropriated by large shareholders. Such results clearly support the expropriation theory generally applied to companies with higher concentration levels or to companies with a weak legal system that places the rights of minority investors at risk by major shareholders.

In addition, the function of representing the owner of state capital is still fragmented and overlapping so the responsibility in management is not clear. The management and administration of many economic groups and corporations are slow to change. In corporate governance, it is still subjective, bureaucratic and psychological based on the "state", etc. Besides, the performance of economic groups and corporations is not commensurate with the scale of capital investment of the government, and thus, there is waste of capital investment due to delayed completion of key investment projects in the fields of energy, transportation, extra expenses, and arising large and prolonged debt between the parties." More specifically, there are inadequacies in the operating mechanism: the contradiction of the operating mechanism between concentration, accumulation (PVN/parent company) and dispersion in management and capital management (subsidiaries are often public joint stock company). To create great competitiveness in international integration, quality of management and corporate governance, state-controlled corporations needs to consider the equitization of the corporation as a whole, and at the same time increase the equity and controlling power of the parent company in subsidiaries.

Secondly, our evidence also indicates that the coefficient of foreign ownership is also negative, consistent with expectations and empirical evidence, but not statistically significant. The ownership ratio of foreign investors in $O \& G$ enterprises in Vietnam accounts for a relatively small proportion. Thus, the incentive to monitor businesses is not strong enough to force managers to pay higher dividends. Moreover, low ownership can make them seem not to interfere with the management's dividend policy.

The foreign investor shareholding percentage is restricted to 49 per cent, which prevent large ownership and control of foreign shareholders and thus reduce the supervision of foreign shareholders on management. In fact, foreign investors participating in the Vietnamese market own relatively small proportions of shares and are less involved in the management of the company. With low ownership, supervision costs can outweigh their supervisory benefits. They have trouble in determining the problems pertaining to enterprises' corporate activities. Without the opportunity to carry out important reforms or apply modern management and technology solutions to enterprises, it will be difficult for foreign investors to support and accelerate the development of the business.

Thirdly, our results show proof that corporate liquidity has a positive impact on the cash dividend policy. High-solvency companies should also pay large dividends. Saghir Ahmed and Hasan Murtaza (2015) observed the beneficial impact of liquidity on dividend payout ratio. If the liquidity ratio decreases, the amount of dividends paid also decreases and vice versa. Companies retain a high degree of equity so as to pay dividends when they come due. Strong liquidity enhances the capacity of 
businesses to pay dividends, while increasing the trust of shareholders.

In this study, we hope to contribute to the literature and to enhance the comprehension of the subject by presenting evidence from Vietnamese O\&G firms. However, this study also has its own limitations. The first limitation comes from the non-fulfillment of Vietnamese data. Vietnam does not have a reliable and readily available database, thus all the Vietnamese data in this study are hand-collected. We also face difficulties while trying to ensure the reliability of Vietnamese data during the data collecting process. We hand-collected data from the audited financial statements of companies; however, the format of financial statements is not uniform. Besides, the annual financial statements are compiled on the basis of fundamental assumptions and definitions that are arbitrary and thus not applied equally, particularly as in regards arrangements and forecasts. Lastly, many financial statements have been reaffirmed in previous years, which ensures that significant business results misrepresentations will provide a window of opportunity for prior-year changes that will not be brought to the public's notice. That means the pattern shown will influence the existing relationship.

Further studies are also required to ensure the results of the analysis are reliable and accurate. The findings of this analysis should therefore be viewed with caution. Potential analysis will also investigate whether the biggest ownership form, i.e. whether the main shareholder is a family or the government, has a significant effect on dividend policy.

\section{References}

[1] Adelegan, O.J., 2003. An empirical analysis of the relationship between cash flow and dividend changes in Nigeria. African Development Review, 15(1), pp.35-49.

[2] Amihud, Y. and Murgia, M., 1997. Dividends, taxes, and signaling: evidence from Germany. The Journal of Finance, 52(1), pp.397-408.

[3] Baltagi, B., H.(2005). Econometric analysis of panel data.

[4] Ben Naceur, S., Goaied, M. and Belanes, A., 2006. On the determinants and dynamics of dividend policy. International review of Finance, 6(1-2), pp.1-23.

[5] Ben-Nasr, H., Boubaker, S. and Rouatbi, W., 2015. Ownership structure, control contestability, and corporate debt maturity. Journal of Corporate Finance, $35, \mathrm{pp} .265-285$.

[6] Bhattacharya, S., 1979. Imperfect information, dividend policy, and" the bird in the hand" fallacy. The Bell Journal of Economics, pp.259-270.

[7] Bhattacharya, S., 1980. Nondissipative signaling structures and dividend policy. The quarterly journal of Economics, 95(1), pp.1-24.

[8] Black, F. and Scholes, M., 1974. The effects of dividend yield and dividend policy on common stock prices and returns. Journal of financial economics, 1(1), pp.1-22.

[9] Borisova, G., Brockman, P., Salas, J.M. and Zagorchev, A., 2012. Government ownership and corporate governance: Evidence from the EU. Journal of Banking \& Finance, 36(11), pp.2917-2934.

[10] Chaganti, R. and Damanpour, F., 1991. Institutional ownership, capital structure, and firm performance. Strategic management journal, 12(7), pp.479-491.
[11] Easterbrook, F.H., 1984. Two agency-cost explanations of dividends. The American economic review, 74(4), pp.650-659.

[12] Ezeoha, A.E. and Okafor, F.O., 2010. Local corporate ownership and capital structure decisions in Nigeria: a developing country perspective. Corporate Governance: The international journal of business in society.

[13] Faccio, M., Lang, L.H. and Young, L., 2001. Dividends and expropriation. American economic review, 91(1), pp.54-78.

[14] Farinha, J., 2003. Dividend policy, corporate governance and the managerial entrenchment hypothesis: an empirical analysis. Journal of Business Finance \& Accounting, 30(9-10), pp.1173-1209.

[15] Gordon, M.J., 1962. The investment, financing, and valuation of the corporation. RD Irwin.

[16] Gugler, K. and Yurtoglu, B.B., 2003. Corporate governance and dividend pay-out policy in Germany. European economic review, 47(4), pp.731-758.

[17] Gugler, K., 2003. Corporate governance, dividend payout policy, and the interrelation between dividends, $\mathrm{R} \& \mathrm{D}$, and capital investment. Journal of Banking \& Finance, 27(7), pp.1297-1321.

[18] Jensen, M. and Meckling, W., 1976. Theory of the firm: Management behavior, agency costs and capital structure. Journal of financial economics, 3(4), pp.30560.

[19] Jensen, M.C., 1986. Agency costs of free cash flow, corporate finance, and takeovers. The American economic review, 76(2), pp.323-329.

[20] Kang, D., 1999. Ownership structure and corporate dividend policy: How large block family owners increase dividend payout and achieve superior firm performance. Division of Research.

[21] Khan, F.A. and Ahmad, N., 2017. Determinants of dividend payout: an empirical study of pharmaceutical companies of pakistan stock exchange (PSX). Journal of Financial Studies \& Research, 16.

[22] Khan, T., 2006. Company dividends and ownership structure: Evidence from UK panel data. The Economic Journal, 116(510), pp.C172-C189.

[23] La Porta, R., Lopez-de-Silanes, F., Shleifer, A. and Vishny, R., 2000. Investor protection and corporate governance. Journal of financial economics, 58(1-2), pp.3-27.

[24] Li, K., Yue, H. and Zhao, L., 2009. Ownership, institutions, and capital structure: Evidence from China. Journal of comparative economics, 37(3), pp.471-490.

[25] Lintner, J., 1956. Distribution of incomes of corporations among dividends, retained earnings, and taxes. The American economic review, 46(2), pp.97-113.

[26] Lintner, J., 1962. Dividends, earnings, leverage, stock prices and the supply of capital to corporations. The review of Economics and Statistics, pp.243-269.

[27] Maury, C.B. and Pajuste, A., 2002. Controlling shareholders, agency problems, and dividend policy in Finland. LTA, 1(2), pp.15-45.

[28] Miller, M.H. and Modigliani, F., 1961. Dividend policy, growth, and the valuation of shares. the Journal of Business, 34(4), pp.411-433.

[29] Miller, M.H. and Rock, K., 1985. Dividend policy under asymmetric information. The Journal of finance, 40(4), pp.1031-1051. 
[30] Pöyry, S. and Maury, B., 2010. Influential ownership and capital structure. Managerial and Decision Economics, 31(5), pp.311-324.

[31] Redding, L.S., 1997. Firm size and dividend payouts. Journal of financial intermediation, 6(3), pp.224-248.

[32] Short, H., Zhang, H. and Keasey, K., 2002. The link between dividend policy and institutional ownership. Journal of corporate Finance, 8(2), pp.105-122.

[33] Smith, C.W. and Warner, J.B., 1979. Bankruptcy, secured debt, and optimal capital structure: Comment. The Journal of Finance, 34(1), pp.247-251.

[34] Stulz, R., 1990. Managerial discretion and optimal financing policies. Journal of financial Economics, 26(1), pp.3-27.
[35] Titman, S. and Wessels, R., 1988. The determinants of capital structure choice. The Journal of finance, 43(1), pp.1-19.

[36] Wen, Y. and Jia, J., 2010. Institutional ownership, managerial ownership and dividend policy in bank holding companies. International Review of Accounting, Banking and Finance, 2(1), pp.8-21.

[37] Zeckhauser, R.J. and Pound, J., 1990. Are large shareholders effective monitors? An investigation of share ownership and corporate performance. In Asymmetric information, corporate finance, and investment (pp. 149-180). University of Chicago Press.

[38] Zou, H. and Xiao, J.Z., 2006. The financing behaviour of listed Chinese firms. The British Accounting Review, 38(3), pp.239-258. 